\title{
Perbedaan Penurunan Suhu Tubuh Tikus Wistar Jantan Dan Betina Yang Mati Akibat Diinduksi Metanol
}

\author{
*Abdul Hakim Nitiprodjo ${ }^{1}$, Titik Kusumawinakhyu ${ }^{1}$ \\ ${ }^{I}$ Fakultas Kedokteran Universitas Muhammadiyah Purwokerto
}

\author{
*) Correspondence Author \\ Abdul Hakim Nitiprodjo \\ Fakultas Kedokteran Universitas Muhammadiyah Purwokerto \\ Email: dulkim_pwt02@yahoo.com
}

\begin{abstract}
Someone who dies will experience a decrease in body temperature from body temperature at the beginning of death, both within normal and abnormal limits to room temperature. Decrease in body temperature according to sex may differ in duration. Coupled with exposure to methanol, it is also possible to influence a decrease in body temperature of the corpse. This study aimed to analyze the differences in body temperature reduction in male and female Wistar rats induced with methanol. This research is an experimental study with a pre and post test control group design approach. The design of this study was to observe the body temperature of male and female Wistar rats while still alive and after death and the duration of decrease in body temperature of male and female Wistar mice after being induced with methanol. The population studied was male and female Wistar rat. Based on the results from analysis test, it can be concluded that there is no significant difference between the decrease in body temperature of male and female Wistar rats that died induced by methanol, but there is a significant difference between the decrease in body temperature of male and female Wistar rats who died induced by methanol and without methanol.
\end{abstract}

Keywords: Body temperature, methanol, sex

\begin{abstract}
Abstrak
Seseorang yang meninggal akan mengalami penurunan suhu tubuh dari suhu tubuh saat awal kematian, baik dalam batas normal maupun abnormal menuju suhu lingkungan. Penurunan suhu tubuh mayat berdasarkan jenis kelamin mungkin dapat berbeda durasinya. Ditambah dengan terpapar metanol, tidak menutup kemungkinan juga dapat mempengaruhi penurunan suhu tubuh mayat. Penelitian ini bertujuan menganalisa perbedaan penurunan suhu tubuh pada tikus Wistar jantan dan betina yang diinduksi dengan metanol. Penelitian ini merupakan penelitian eksperimental dengan pendekatan pre dan post test control group design. Rancangan penelitian ini untuk mengamati suhu tubuh tikus Wistar jantan dan betina saat masih hidup dan setelah mati serta durasi penurunan suhu tubuh tikus Wistar jantan dan betina setelah diinduksi dengan metanol. Populasi yang diteliti adalah tikus Wistar jantan dan betina. Data tersebut dianalisis dengan uji Independent-Samples Median. Berdasarkan hasil penelitian dari uji analisis dapat disimpulkan bahwa tidak terdapat perbedaan bermakna antara penurunan suhu tubuh tikus Wistar jantan dan betina yang mati diinduksi metanol, namun terdapat perbedaan bermakna antara penurunan suhu tubuh tikus Wistar jantan dan betina yang mati diinduksi metanol dan tanpa metanol.
\end{abstract}

Kata kunci: Suhu tubuh, metanol, jenis kelamin 


\section{PENDAHULUAN}

Seseorang yang meninggal akan mengalami penurunan suhu tubuh dari suhu tubuh saat awal kematian, baik dalam batas normal maupun abnormal (hiperthermi, hipothermi) menuju suhu ruang atau lingkungan ${ }^{1}$. Tidak sedikit orang yang meninggal akibat minuman keras oplosan yang di dalamnya terdapat kandungan metanol. Sekitar bulan April 2018, total korban di Kabupaten Bandung mencapai 145 orang dengan kematian 41 orang. Di RSUD Cicalengka ada 103 orang dirawat dan 31 orang meninggal, di RSUD Majalaya ada 60 pasien dan meninggal 3 orang, serta di RS AMC ada 16 korban dirawat dan meninggal 7 orang. Kejadian tersebut merupakan kasus keracunan metanol ${ }^{2}$.

Penurunan suhu tubuh pada mayat laki-laki dan perempuan mungkin dapat berbeda durasinya. Ditambah dengan terpapar metanol, tidak menutup kemungkinan juga dapat mempengaruhi penurunan suhu tubuh mayat. Untuk membuktikan pernyataan di atas, maka dilakukan eksperimen pada hewan coba tikus Wistar. Penelitian ini bertujuan untuk menganalisa perbedaan penurunan suhu tubuh pada tikus Wistar jantan dan betina yang diinduksi dengan metanol.

Manusia akan mengalami proses yang terjadi setelah mati klinis, dimulai dari timbulnya lebam mayat, kaku mayat, dan penurunan suhu tubuh yang dapat muncul secara bersamaan (Di Maio, 2007). Kulit muka mengalami perubahan, dimana raut muka tampak lebih pucat. Otot-otot mengalami relaksasi primer, pada otot-otot muka memberi kesan lebih muda. Lapisan kornea mengering. Dilanjutkan dengan dekomposisi yang akan terjadi minimal 24 jam setelah mati klinis ${ }^{9}$.

Durasi masing-masing proses setelah mati klinis mungkin dapat lebih cepat atau lebih lambat karena berbagai faktor. Misal karena terinduksi suatu zat beracun. Sesudah mati, metabolisme yang menghasilkan panas akan terhenti sehingga suhu tubuh akan turun menuju suhu udara atau medium di sekitarnya. Penurunan ini disebabkan oleh adanya proses radiasi, konduksi, dan pancaran panas ${ }^{9}$.

Pada jam-jam pertama setelah mati (tidak lebih dari 3 jam setelah korban mati), penurunan suhu tubuh sangat lambat karena masih adanya produksi panas dari proses glikogenolisis, tetapi setelah 3 jam penurunan suhu menjadi lebih cepat dan setelah 9 jam mati penurunan suhu menjadi lambat kembali serta menyamai suhu lingkungan. Kalau proses penurunan tersebut digambarkan dalam bentuk grafik, maka grafiknya menyerupai sigmoid atau huruf $\mathrm{S}$ terbalik ${ }^{1}$. Pengukuran suhu tubuh mayat 
dapat dilakukan per rektal dengan menggunakan termometer kimia yang panjang ${ }^{7}$.

Penurunan suhu tersebut dapat dipengaruhi oleh berbagai faktor, antara lain:

a. Suhu tubuh pada saat mati

Suhu tubuh yang tinggi pada saat mati, misal pada penderita infeksi atau perdarahan otak mengakibatkan tingkat penurunan suhu lebih cepat. Sedangkan penderita dengan hipotermi, tingkat penurunan suhu lebih lambat.

b. Suhu medium

Semakin rendah suhu medium tempat tubuh mayat berada semakin cepat tingkat penurunannya.

c. Keadaan udara di sekitarnya

Pada udara lembab, tingkat penurunan suhu menjadi lebih besar. Hal ini disebabkan karena udara lembab merupakan konduktor yang baik. Pada udara yang terus berhembus, tingkat penurunan suhu juga semakin cepat.

\section{d. Jenis medium}

Pada medium air, tingkat penurunan suhu lebih cepat sebab air merupakan konduktor yang baik.

e. Keadaan tubuh mayat

Pada mayat bayi, tingkat penurunan suhu lebih cepat dibandingkan mayat orang dewasa. Hal ini karena pada bayi, luas permukaan tubuh relatif lebih besar.Pada mayat yang tubuhnya kurus, tingkat penurunan suhu juga lebih cepat dibandingkan dengan mayat bertubuh gemuk.

\section{f. Pakaian mayat}

Semakin tipis pakaian yang dipakai, semakin cepat tingkat penurunan suhu tubuh ${ }^{2}$.

Faktor-faktor yang lain seperti jenis kelamin dan karena suatu zat yang toksik mungkin dapat mempengaruhi durasi dan bentuk grafik penurunan suhu tubuh.

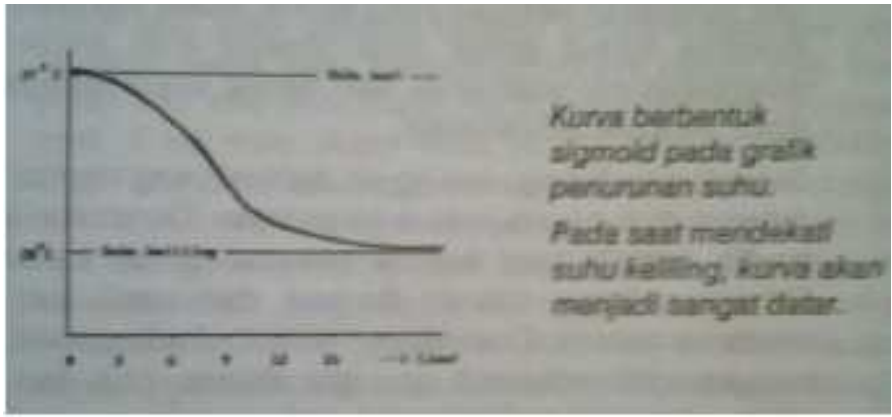

Gambar 1. Grafik penurunan suhu tubuh mayat menyerupai $\mathrm{S}$ terbalik ${ }^{1}$

Tidak sedikit orang yang meninggal akibat keracunan minuman keras yang mengandung alkohol terutama minuman keras oplosan. Minuman keras oplosan dapat berisi campuran etanol dan metanol. Metanol atau metil alkohol (alkohol kayu) merupakan senyawa alkohol yang digunakan untuk keperluan industri, kesenian dan peralatan rumah tangga, bukan untuk minuman. Bentuk fisik berupa cairan jernih tidak berwarna dengan sedikit bau aromatis, memiliki titik didih $60-70{ }^{\circ} \mathrm{C}{ }^{4}$. Kadar ambang batas metanol di udara adalah 200 ppm. Bau 
metanol akan tercium bila kadar di udara mencapai 100 ppm. Takaran toksik diperkirakan $6 \mathrm{ml}$, dan takaran letal sekitar $30-100 \mathrm{ml}^{1}$.

Metanol dibuat dari destilasi kayu atau melalui sintesis kimia. Banyak digunakan dalam bidang industri dan kesenian, terutama sebagai pelarut cat ${ }^{1}$. Metanol hasil destilasi sering mengandung pengotoran seperti furfurol, metil dan dimetil asetat, alkil alkohol maupun etil dimetil keton ${ }^{4}$.

Keracunan terjadi karena beberapa hal. Paling banyak karena kecelakaan, antara lain:

- Kekeliruan minum karena disangka minuman keras

- Pemalsuan minuman keras dengan menambahkan metanol pada minuman keras

Kadang-kadang karena bunuh diri. Karena tujuan pembunuhan jarang terjadi ${ }^{5}$.

Metanol masuk ke dalam tubuh melalui mulut, kulit, dan inhalasi. Absorpsi melalui inhalasi misalnya terjadi bila menghirup uap cat (pelitur) dalam ruang tertutup, pada pembuatan esens dan sebagainya. Metanol dalam tubuh diubah menjadi formaldehida oleh $\mathrm{ADH}$ (alkohol dehidrogenase). Kemudian formaldehida akan menjadi asam format oleh FDH (formaldehidrogenase). Sebagian kecil metanol diekskresikan dalam bentuk tidak berubah melalui paru. Ekskresi melalui urin sangat sedikit.

Dalam urin, asam format dapat ditemukan hingga 12 hari kemudian 5 .

Metanol bekerja menekan susunan saraf pusat tanpa didahului eksitasi. Efek depresi metanol lebih kecil dibandingkan dengan etanol, tetapi sebaliknya efek iritasi metanol lebih besar daripada etil alkohol ${ }^{3}$. Metanol lebih toksik daripada etanol karena hasil dekomposisinya yang sangat toksik dan karena efeknya yang lebih lama akibat ekskresi yang lebih lambat ${ }^{3}$.

Hasil metabolitnya bersifat toksik, maka umumnya gejala timbul tiba-tiba setelah masa laten yang lamanya sangat bervariasi. Keracunan metanol menunjukkan gejala rasa lemah, mual, muntah, sakit kepala, sesak nafas, dan sianosis. Kemungkinan dapat diikuti pula dengan delirium, kejang, kulit teraba dingin (temperatur tubuh turun), stupor, dan koma. Gejala-gejala ini timbul akibat depresi SSP, edema otak, dan akibat oksidasi metanol yang menyebabkan $\operatorname{asidosis}^{1}$

Kebutaan dapat terjadi pada keracunan akut dan kronik metanol sebagai akibat kerja racun pada sel ganglion retina yang menimbulkan atrofi nervus optikus. Kebutaan sudah dapat terjadi apabila terminum metanol sebanyak $15 \mathrm{ml}^{6}$. 
Keracunan metanol umumnya terjadi akibat kecelakaan. Takaran mematikan adalah $30-100 \mathrm{ml}$. Kematian umumnya terjadi dalam 24 - 36 jam. Kematian segera setelah keracunan terutama karena paralisis pusat pernafasan ${ }^{4}$.

Tanda-tanda pada jenazah tidak khas. Pada pemeriksaan luar kemungkinan hanya tercium bau khas dan tanda-tanda asfiksia ${ }^{1}$. Pada pembedahan jenazah dapat ditemukan kongesti (perbendungan) alat-alat dalam atau vena organ dalam, pembengkakan paru, perdarahan pada permukaan paru dan mukosa alat dalam (hiperemi mukosa lambung dan usus hingga saluran pencernaan atas), dan bintik-bintik perdarahan pada selaput otak ${ }^{3}$.

Pada pemeriksaan histopatologik dapat dijumpai degenerasi bengkak keruh pada hati dan ginjal serta edema otak, degenerasi ganglion sel saraf penglihatan dan ganglion sel otak besar, perdarahan kecil-kecil di medulla oblongata ${ }^{4}$.

Bahan-bahan yang perlu diambil untuk pemeriksaan toksikologi metanol adalah darah, otak, hati, ginjal, dan urin. Dalam urin dapat ditemukan metanol dan asam formiat/ asam format sampai 12 hari setelah keracunan ${ }^{5}$.

Salah satu yang menjadi pertanyaan adalah apakah metanol dapat mempengaruhi durasi penurunan suhu tubuh mayat atau tidak, belum dapat dibuktikan dengan jelas. Metanol dalam metabolismenya juga menghasilkan kalor yang mungkin dapat mempengaruhi penurunan suhu tubuh mayat. Ditambah faktor jenis kelamin apakah juga dapat mempengaruhi hal tersebut atau tidak.

\section{METODE}

Rancangan penelitian yang digunakan adalah pendekatan pre dan post test control group design, yang bertujuan untuk mengamati suhu tubuh tikus Wistar jantan dan betina saat masih hidup dan setelah mati serta durasi penurunan suhu tubuh setelah diinduksi dengan metanol. Populasi yang diteliti adalah tikus Wistar jantan dan betina

Kriteria sampel terdiri dari kriteria inklusi dan eksklusi.

Kriteria inklusi:

a. Tikus jantan dan betina sehat dan gerak aktif

b. Umur 2-3 bulan

c. Berat badan $150-200$ gram

Kriteria eksklusi:

a. Tikus mati atau dalam keadaan sakit sebelum mendapat perlakuan

b. Berat badan $<150$ gram dan $>200$ gram Sampel penelitian ini ditentukan menurut rumus Federer untuk uji eksperimental, yaitu (t-1) (n1) $\geq 15$. (t) adalah jumlah kelompok perlakuan, dan 
(n) adalah jumlah sampel per kelompok perlakuan.

Terdapat empat kelompok perlakuan dan jumlah sampel masing-masing kelompok adalah tujuh. Sehingga total sampel dalam penelitian ini adalah 28 .

Dalam penelitian ini dibagi, yaitu dua kelompok tanpa diinduksi metanol dan dua kelompok yang diinduksi metanol. Dosis yang digunakan untuk induksi adalah $6-8 \mathrm{ml}$.

Data yang diperoleh dianalisis dengan menggunakan software pengolah data statistik dengan uji normalitas data (Shapiro-Wilk) dan homogenitas (Levene). Jika data terdistribusi normal dan homogen, maka dilanjutkan dengan uji analisis varian satu arah (one way ANOVA). Jika salah satu syarat untuk uji ANOVA tidak terpenuhi, maka dilakukan uji Kruskal-Wallis. Apabila terdapat perbedaan bermakna, dilakukan uji Mann-Whitney untuk melihat perbedaan antar kelompok perlakuan ${ }^{8}$.

\section{HASIL DAN PEMBAHASAN}

Penelitian dilakukan di Laboratorium Farmakologi Fakultas Kedokteran Universitas Muhammadiyah Purwokerto. Tikus dibagi menjadi empat kelompok. Kelompok pertama berisi 7 tikus jantan tanpa diinduksi metanol, kelompok kedua berisi 7 tikus betina tanpa diinduksi metanol, kelompok ketiga berisi 7 tikus jantan dengan diinduksi metanol, dan kelompok keempat berisi 7 tikus betina dengan diinduksi metanol.

Pada tanggal 3 dan 4 Maret 2020 dilakukan penelitian pada kelompok tikus jantan yang diinduksi dengan metanol secara oral dengan sonde. Dilakukan pengukuran suhu tubuh dengan termometer infra red melalui permukaan tubuh tikus sebelum dan setelah diinduksi dengan metanol. 
Tabel 1. Perlakuan tikus Wistar jantan yang diinduksi dengan metanol

\begin{tabular}{|c|c|c|c|c|c|c|c|}
\hline \multirow{5}{*}{$\begin{array}{l}\text { Animal } \\
\text { temperature } \\
\text { (derajat } \\
\text { Celcius) }\end{array}$} & \multicolumn{7}{|c|}{ Waktu } \\
\hline & \multirow{4}{*}{\begin{tabular}{|c|}
$\begin{array}{c}\text { Sebelum } \\
\text { diinduksi } \\
\text { metanol }\end{array}$ \\
3 Maret \\
2020 \\
16.30
\end{tabular}} & \multicolumn{6}{|c|}{ Setelah diinduksi metanol dan mati } \\
\hline & & \multicolumn{3}{|c|}{3 Maret 2020} & & \multirow{2}{*}{\multicolumn{2}{|c|}{4 Maret 2020}} \\
\hline & & & & & & & \\
\hline & & $16.35 \mathrm{~s} / \mathrm{d} 17.30$ & $17.30 \mathrm{~s} / \mathrm{d} 17.40$ & 17.40 & 17.46 & 13.00 & 13.05 \\
\hline Tikus I & 35,3 & - & 34,6 & 34,6 & 34,1 & 34,6 & 34,6 \\
\hline Tikus II & 35,3 & 35,7 & 34,4 & 34,2 & 34 & 34,5 & 34,8 \\
\hline Tikus III & 35,4 & 35 & 35,2 & 34 & 34,3 & 34,7 & 34,2 \\
\hline Tikus IV & 35,5 & 34,9 & 34,9 & 34,9 & 34,9 & 34,8 & 34,8 \\
\hline Tikus V & 35,6 & - & 35,2 & 34,3 & 34,3 & 35 & 34,8 \\
\hline Tikus VI & 35,3 & 35,3 & 35,2 & 34,2 & 34,2 & 34,9 & 34,9 \\
\hline Tikus VII & 35,2 & - & 35,2 & 35,2 & 34,1 & 34,9 & 34,9 \\
\hline
\end{tabular}

Suhu ketujuh ekor tikus jantan diukur sebelum diinduksi metanol. Kelima ekor tikus (tikus II - VI) mati setelah diinduksi metanol dengan kadar $6 \mathrm{ml}$, tikus I baru mati setelah diinduksi metanol dengan kadar $8 \mathrm{ml}$, dan tikus VII baru mati setelah diinduksi metanol dengan kadar 7,2 $\mathrm{ml}$. Hal tersebut terjadi karena adanya efek toleransi metanol pada tubuh, sehingga efek untuk menimbulkan kematian pada setiap manusia atau hewan bervariasi (Di Maio, 2007). Setelah semuanya diinduksi dengan metanol dan mati, suhu tubuh dari masing-masing tikus jantan tidak mengalami penurunan yang tajam selama 20 jam.

\section{Pada tanggal 14 April 2020 dilakukan} penelitian pada kelompok tikus jantan tanpa induksi dengan metanol. Diukur suhu tubuh dengan termometer digital biasa per rektal sebelum dan setelah diinduksi dengan kloroform yang dilanjutkan dengan dekapitasi.

Tabel 2. Perlakuan tikus Wistar jantan yang diinduksi kloroform dan dekapitasi

\begin{tabular}{lcccc}
\hline $\begin{array}{l}\text { Suhu hewan coba } \\
\text { (derajat Celcius) }\end{array}$ & \multicolumn{4}{c}{ Waktu } \\
\cline { 2 - 5 } & $\begin{array}{l}\text { Sebelum } \\
\text { kloroform } \\
\text { dekapitasi }\end{array}$ & $\begin{array}{c}\text { diinduksi } \\
\text { dan }\end{array}$ & & \multicolumn{2}{c}{ Setelah diinduksi kloroform dan dekapitasi } \\
\cline { 2 - 5 } & $11.23 \mathrm{~s} / \mathrm{d} 12.06$ & $11.47 \mathrm{~s} / \mathrm{d} 12.16$ & 12.30 & Lo \\
\hline Tikus I & 34,4 & 32 & Lo & Lo \\
Tikus II & 34,1 & 32,9 & Lo & Lo \\
Tikus III & 32,8 & 33,5 & Lo & Lo \\
Tikus IV & 32,9 & 32 & Lo & Lo \\
Tikus V & 32,9 & 32,8 & & \\
\hline
\end{tabular}


Pada waktu pertama (11.23 s/d 12.06) dan kedua (11.47 s/d 12.16), suhu terukur dengan jelas, namun pada waktu ketiga (12.30) dan keempat (13.00), indikator suhu menunjukkan "Lo" yang berarti suhu kelima tikus jantan rendah atau mendekati suhu kamar/ ruang berkisar $26-27{ }^{\circ} \mathrm{C}$. Hal tersebut menunjukkan adanya penurunan suhu yang cepat dalam waktu sekitar satu jam setelah mati.

Pada tanggal 22 Juni 2020 dilakukan penelitian tikus betina yang terbagi menjadi dua kelompok perlakuan, yaitu diinduksi dengan metanol

Tabel 3. Perlakuan tikus Wistar betina yang diinduksi dengan metanol

\begin{tabular}{|c|c|c|c|c|c|c|c|}
\hline \multirow{3}{*}{$\begin{array}{l}\text { Suhu hewan coba } \\
\text { (derajat Celcius) }\end{array}$} & \multicolumn{7}{|c|}{ Waktu } \\
\hline & \multirow{2}{*}{$\begin{array}{l}\begin{array}{l}\text { Sebelum diinduksi } \\
\text { dengan metanol }\end{array} \\
12.46\end{array}$} & \multicolumn{6}{|c|}{ Setelah diinduksi metanol dan mati } \\
\hline & & 13.00 & 13.15 & 14.00 & 14.10 & 14.20 & 14.30 \\
\hline Tikus I & 36 & 36 & 34,2 & 34 & 32,2 & 32,3 & 32,2 \\
\hline Tikus II & 35,7 & 35,4 & 35,2 & 34,9 & 32,1 & 32,3 & 32,1 \\
\hline Tikus III & 35,8 & 36 & 35,3 & 33,4 & 32,3 & 32,1 & 32,6 \\
\hline Tikus IV & 36,1 & 35,2 & 35,2 & 34,9 & 33 & 32,5 & 32,5 \\
\hline Tikus V & 35,4 & - & - & 35,1 & 33,2 & 33 & 32,3 \\
\hline Tikus VI & 35,6 & - & - & 35,1 & 34,7 & 32,5 & 32,6 \\
\hline Tikus VII & 35,9 & - & - & 34,7 & 33,8 & 33,2 & 33,8 \\
\hline
\end{tabular}

dan tanpa metanol. Pada kelompok pertama, suhu tubuh diukur dengan termometer infra red melalui permukaan tubuh tikus sebelum dan setelah diinduksi dengan metanol. Pada kelompok kedua, suhu tubuh diukur dengan termometer infra red melalui permukaan tubuh tikus sebelum dan setelah diinduksi dengan kloroform yang dilanjutkan dengan dekapitasi. 
Suhu ketujuh ekor tikus betina diukur sebelum dan setelah diinduksi dengan metanol secara oral dengan sonde. Setelah diinduksi dan mati, suhu tubuh dari masing-masing tikus betina tidak mengalami penurunan yang tajam selama 1,5 jam. Tikus I - IV mati setelah diinduksi dengan metanol dengan kadar 6 ml, sedangkan tikus V - VII baru mati sekitar jam 14.00 setelah diinduksi metanol dengan kadar $8 \mathrm{ml}$. Hal ini juga terjadi karena efek toleransi dari metanol.

\section{Analisa Statistik}

Dari uji normalitas data (Kolmogorov-Smirnov dan Shapiro-Wilk) diperoleh $\mathrm{p}=0,000$, maka data terdistribusi tidak normal. Oleh karena itu yang dipakai adalah uji non parametrik. Perbedaan penurunan suhu tubuh tikus jantan dan betina yang diinduksi dengan metanol menggunakan uji Independent-Samples Median dan diperoleh $\mathrm{p}=0,682$, maka tidak terdapat perbedaan bermakna antara penurunan suhu tubuh tikus jantan dan betina yang diinduksi dengan metanol. Pada perbedaan penurunan suhu tubuh tikus betina

Tabel 4. Perlakuan tikus Wistar betina yang diinduksi kloroform dan dekapitasi

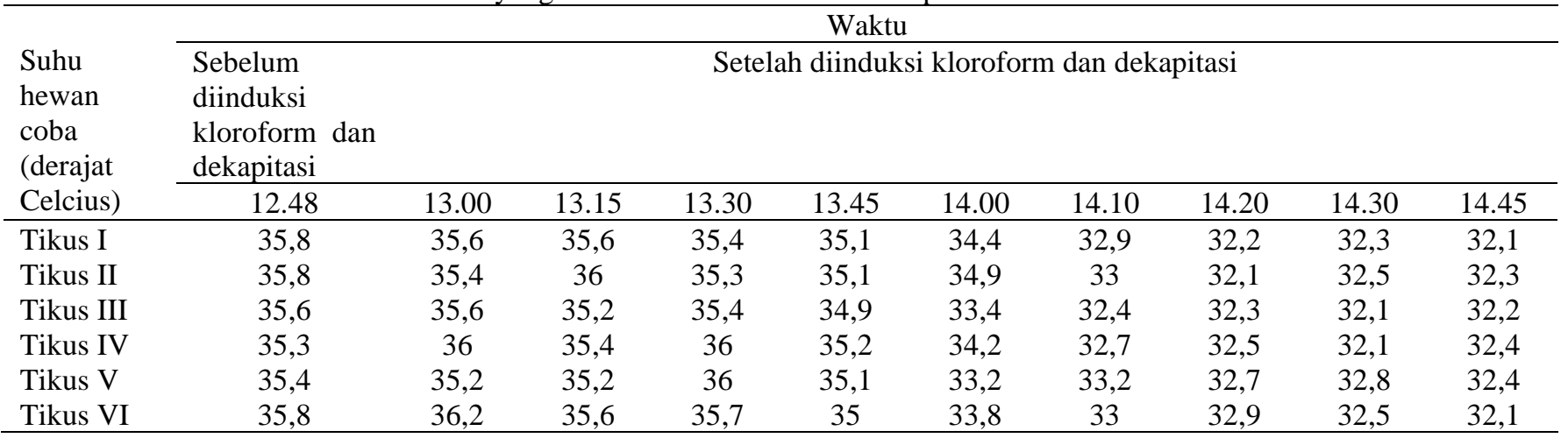

Suhu keenam ekor tikus betina diukur sebelum

dan setelah diinduksi dengan kloroform dan didekapitasi. Setelah diinduksi dan didekapitasi, suhu tubuh dari masing-masing keenam ekor tikus betina juga tidak mengalami penurunan yang tajam selama hampir dua jam.

Kedua kelompok perlakuan pada tikus betina tidak menunjukkan perbedaan yang menonjol pada penurunan suhu setelah mati, baik yang diinduksi dengan metanol maupun tanpa metanol. yang mati diinduksi dengan metanol dan tanpa metanol menggunakan uji Independent-Samples (Levene's test) dan diperoleh $\mathrm{p}=0,000$, maka terdapat perbedaan bermakna antara penurunan suhu tubuh tikus betina yang mati diinduksi dengan metanol dan tanpa metanol.

Pada perbedaan penurunan suhu tubuh tikus jantan dan betina yang mati diinduksi dengan metanol dan tanpa metanol menggunakan uji IndependentSamples Median dan diperoleh $\mathrm{p}=0,036$, maka terdapat perbedaan bermakna antara penurunan suhu 
tubuh tikus jantan dan betina yang mati diinduksi dengan metanol dan tanpa metanol. Dengan demikian dapat dinyatakan bahwa perbedaan jenis kelamin tidak mempengaruhi penurunan suhu tubuh tikus setelah mati, sedangkan adanya induksi dengan metanol dapat mempengaruhi penurunan suhu tubuh tikus setelah mati.

Semua tikus betina dan jantan yang mati dengan dosis metanol yang bervariasi tidak hanya karena toleransi tubuh terhadap suatu zat, tetapi juga faktor lambung dan usus berkaitan dengan tikus dalam keadaan lapar atau tidak. Pada umumnya, tikus dalam keadaan lapar memiliki daya cerna dan serap yang lebih kuat dibandingkan dengan tikus yang tidak lapar. Oleh karena itu beberapa tikus dalam kondisi lapar akan lebih mudah menyerap zat beracun dengan dosis tertentu, sehingga efek kematian timbul lebih cepat (Di Maio, 2007).

\section{SIMPULAN}

1. Tidak terdapat perbedaan antara penurunan suhu tubuh tikus Wistar jantan dan betina yang diinduksi dengan metanol.

2. Terdapat perbedaan antara penurunan suhu tubuh tikus Wistar betina yang mati diinduksi dengan metanol dan tanpa metanol.

3. Terdapat perbedaan antara penurunan suhu tubuh tikus Wistar jantan dan betina yang mati diinduksi dengan metanol dan tanpa metanol.
4. Perbedaan jenis kelamin tidak mempengaruhi penurunan suhu tubuh tikus Wistar setelah mati, sedangkan ada atau tidaknya induksi dengan metanol dapat mempengaruhi penurunan suhu tubuh tikus Wistar setelah mati.

\section{DAFTAR PUSTAKA}

1. Budiyanto, Arif, dkk. 1997. Ilmu Kedokteran Forensik, Cetakan Kedua. Bagian Kedokteran Forensik Fakultas Kedokteran Universitas Indonesia, Jakarta

2. Dahlan, Sofwan. 2007. Ilmu Kedokteran Forensik, Pedoman Bagi Dokter dan Penegak Hukum. Badan Penerbit Universitas Diponegoro, Semarang

3. Di Maio, Vincent J. 2007. Forensic Pathology, Second Edition. CRC Press, Florida

4. Hoediyanto dan Hariadi A. 2010. Buku Ajar Ilmu Kedokteran Forensik dan Medikolegal: Thanatologi. Fakultas Kedokteran Universitas Airlangga, Surabaya

5. Idries, A., M.. 1997. Pedoman Ilmu Kedokteran Forensik. Binarupa Aksara, Jakarta

6. Idries, A., M., Agung L.. 2013. Penerapan Ilmu Kedokteran Forensik dalam Proses Penyidikan. CV Sagung Seto, Jakarta

7. Kumar, V. et al. 1997. Basic Pathology, 6th Ed. WB Saunders Company, Philadelphia

8. Sastroasmoro, Sudigdo dan Sofyan Ismael. 2008. Dasar-dasar Metodologi Penelitian Klinis, Edisi Ketiga. Penerbit CV Sagung Seto, Jakarta

9. Suharto, Gatot, dkk. 2010. Tanya Jawab Ilmu Kedokteran Forensik: Thanatologi, Edisi Kedua. Badan Penerbit Universitas Diponegoro, Semarang 10. https://www.republika.co.id $>$ berita $>$ nasional $>$ daera h. Diunduh tanggal 15-08-2019 